International Journal of Linguistics, Literature and Translation

ISSN: 2617-0299 (Online); ISSN: 2708-0099 (Print)

DOI: $10.32996 /$ ijllt

Journal Homepage: www.al-kindipublisher.com/index.php/ijltt

\title{
Suggested Strategies for Writing Narrative Essay
}

\author{
Suha Idress Mohammed \\ Nineveh Directorate of Education, Ministry of Education, Iraq
}

$\square$ Corresponding Author: Suha Idress Mohammed, E-mail: suhaninawa@gmail.com

\section{ARTICLE INFORMATION}

Received: 04 October 2021

Accepted: 19 November 2021

Published: 08 December 2021

DOI: 10.32996/ijllt.2021.4.12.4

\section{KEYWORDS}

Skills, Writing, learning, strategies, narrative essay.

\section{ABSTRACT}

Learning strategies are many, varied, and very important, especially when it comes to expressing and narrating events. Learning to write a narrative essay in the second language is essential, and writing articles by following special strategies develops the second language for the learner and opens new horizons for him in the field of language learning. Using methods and strategies while teaching pupils makes students more intelligent and aware and not make mistakes that they may make while writing articles or narrating on any topic. The study aims at helping students to start writing and ultimately to produce more writing and Encourage fluency in generating ideas for writing on any topic. Moreover, this work will help students begin organizing ideas. The research also includes the study of writing the narrative essay, how to write it, its patterns, and knowledge. The study ends with a conclusion that summarizes the current study.

\section{Introduction}

It is often believed that writing is a hard skill to master. The elements of writing are crucial for students who are learning writing skills. According to Blanchard and Root (1998), as cited in Mundriyah \& Parmawati (2016), it's not always easy to learn to write in a new language. Similarly, the works of (Heaton, 1995) revealed that the skill is difficult and at times hard to teach, needs a good mastering in both grammatical and rhetorical devices and judgmental and conceptual elements. In line with the works of (Harmer, 1991), he claims that students encounter difficulties in each skill but writing is the toughest skill to be learned since it's a production skill and requires feedback. In the word, learners must be capable of improving ideas, arranging the text context, applying appropriate grammar, selecting the lexical and structure forms, and making the presentation of appropriate punctuation and spelling in line with the text.

Handling the difficulties that arise during the writing process can be solved by applying strategies, particularly in teaching. The strategies can make students improve their writing skills and also the strategies encourage the learners to write and offer them a chance to practice the writing skill and hence solve the difficulties that are encountered by students.

\subsection{Research problem}

According to Hicks (1993), It has been the goal of the American school system to teach children to write compositions since the colonial era. Recently, there has been a rise in the awareness of the essence of writing, resulting in a higher focus placed on writing. This should have led to increasingly enhancing the writing skills of our students but unfortunately, this has not been the case.

1. Students find difficulty in writing a narrative essay.

2. They lack fluency in generating and organizing ideas, so this study tries to help students to suggest new strategies to write a narrative essay in their own style.

\subsection{Aims of the Study \\ 1. Helping students to start writing and ultimately to produce more writing. \\ 2. To encourage fluency in producing ideas for writing on any topic, in any subject area. \\ 3. Help learners to begin organizing ideas.}

\subsection{Procedure}

Copyright: (C) 2021 the Author(s). This article is an open access article distributed under the terms and conditions of the Creative Commons Attribution (CC-BY) 4.0 license (https://creativecommons.org/licenses/by/4.0/). Published by Al-Kindi Centre for Research and Development, London, United Kingdom. 
This research includes four chapters, where, the first chapter includes the introduction of the research, while the second chapter includes the review of literature related to the research. The third chapter contains the analysis and discussion. Finally, the fourth chapter where include the conclusion of the research.

\section{Literature Review}

A narrative essay gives a story. Actually, the narrative is a synonym of a story. This section will teach the writing and organization of a narrative essay. Although narrative essays share the same structural form as many other academic essays, it enables a writer to be extra creative as compared to other academic essays. Narratives can give long stories or just some minutes' worth of excitement. According to Begum, (2005), whereas the structure of a narrative essay observes a certain structure, narrative ideas are mostly used in various writing tasks like argument or compare-contrast.

The paragraph that begins a story usually is the introduction of narrative essays. It describes the story's setting, introduces the characters, and prepares the audience for the upcoming action. According to Begum, (2005: 34), the introduction should encompass a hook and a thesis.

ESL: Sentence structure is the arrangement of words in an English sentence. Because it observes a rather rigid formula, English learners must know it to be comprehensible (Calkins, 1987).

Children know that decent stories should have an interesting introduction, progressive development, and finally, a climax. But in their writing, their stories usually have an interesting start. However, the progression of events lacks proper arrangement and the endpoint usually lacks. Mostly, the story ends with the triumphant words "The End." The works of (Petty, and Becking, 1981: 76), depicted that it's the role of educators to implement good writing habits.

The review of various studies reveals that numerous strategies, activities, and techniques have been put in place to aid students to improve as writers and assist learners in portraying a positive attitude to writing Atwell, (1987).

MacArthur, Graham, Schwartz, and Schafer investigated a writing instruction model that incorporated strategy instruction, word processing, and a process approach in 1995. They aimed to develop writers who have basic writing skills; malleable cognitive tactics for planning, revising, and writing; skills on writing for different purposes, and increase their motivation to apply writing in their day-to-day lives. The study applied a comprehensive approach to instruction writing. These goals are suitable for all learners. They have a unique meaning for learners with learning disabilities (Atwell, 1987: 22).

The writer sampled seven self-contained classes for elementary school students who had learning disabilities during the first year. $19 \%$ of the sample were female and $40 \%$ incorporated the minority. Control sites included seven similar classes. $46 \%$ were minorities and 27 were female. The writer sampled five classes for learners with learning disabilities during the second year. The percentage for females was thirty-two while the minority percentage was thirty-seven. Control sites included three classes. The minority percentage was thirty-eight while thirty-one percent were female. The range of class sizes was eight to fifteen students. The years ranged from 10.5 to 11.0. Teachers accepted to participate in the study as volunteers. Every class in an experimental group was offered 4 to 6 computers or daily accessed computer laboratory Caldwell, (1991).

Teachers started the year with a main writing workshop program. The workshop involved daily writing, selection of learners for particular topics, teacher's conferences and mini-lessons, editing and revising, and publishing. Also, at the beginning of the year, students were introduced to the word processor operation and the introduction of regular keyboarding practice by their teachers. Furthermore, teachers encouraged learners to write about their personal experiences. There was the first introduction of the peer revising strategy. Then the introduction of the planning strategy came second. There was writing of two personal narratives and two informative prompts and counterbalanced across time by assigning prompts randomly to the class for the pretest (Collins, 1985: 65).

Students wrote informative papers and narrative both at pretest and posttest. The learners were given enough sitting time to complete the papers. They were not allowed to use any reference materials and also get any kind of assistance from anyone. The experimental learners were assigned randomly to do the posttest with or without the computer. Each sample of writing was transcribed on a word processor before scoring. Compositions were ranged and gauged on an eight-point scale where one represented the lowest and eight the highest quality. Distinct one-way analyses of variance by prompt were conducted for quality of narratives and length and informative papers. All comparisons were non-significant (Dahl, 1988). 
The works of (Oshima, 2007), states that a narrative is a type of writing that is done when someone tells a story and uses time order words and phrases to show the time of occurrence of each part of a story Begum, (2005: 37), (cf. Hazem and Mohammed, 2021).

\subsection{Essay Writing}

Essay writing is an academic practice that improves learners' critical thinking, analytical skills, writing, and reflection. Apart from giving learners a platform for applying these skills, essay writing enables them to develop appropriate communication skills by use of 5 parts of an essay. Thereby, scholars tend to write different essays, including expository, comparative, narrative, persuasive, and argumentative. The selection of the kind of essay to be written by students and the instructors determine the topic. Though, authors can select essay themes in case they have the options. When learners write an easy of five paragraphs, they should ensure the content is captured in five parts that talk about distinct but related subjects. The sections should incorporate the introduction, supporting details covered in three body paragraphs, and the conclusion. Besides, familiar five-paragraph essays are argumentative, whereby the three body paragraphs talk about the argument, counters the argument, and rebuttal (Petty, and Becking, 1981).

\subsubsection{Part one: Introduction:}

The introduction is basic and mandatory for the start of any academic writing. In line with the 5 parts of an essay, the introduction gives an overview of the author's main idea in the main text. Here, students must consider three factors: they capture the reader's attention, contextualise their idea, and make it clear the aim of the text. Generally, the introduction encompasses a hook, the topic's background information, and a thesis statement.

\subsubsection{Part Two: Arguments}

The body is the second part of the 5 parts of an essay. Generally, learners delve into the topic by coming up with evidence that supports their thesis. For instance, writers give readers enough details concerning the topic by use of the thesis statement as a guiding factor. In a five-paragraph essay, The first section of the body focuses on the arguments of the writer. For instance, putting into consideration the marijuana legalization topic and the thesis statement that states the benefits of legalizing marijuana outweighs the effects, writers use this part to give evidence of the claim. Authors should also check related scholarly articles to look for evidence to back up their claims to make their argument trustworthy. This means that scholarly, published articles and books act as sources of evidence for the research (Begum, 2005: 40).

\subsubsection{Part Three: Counter Argument}

This is the third part of 5-parts of an essay, which comes as the second part of the main text. It focuses on counterarguments. In reality, it is useless for a writer to put down arguments for a certain issue without considering divergent opinions. Hence, in this part, the author looks at the critics' literature conducted by various scholars that is related to the topic. To ensure the paper is standard, authors must back up the counter-arguments with evidence from academic sources (Collins, 1985).

\subsubsection{Part four: Rebuttal}

This is the fourth section of a 5-paragraph argumentative essay and comes as the third section of the main text. After providing arguments that criticize the main argument in the thesis, learners are supposed to refute the claim. In short, the author should challenge the counter-arguments to defend the claim that is portrayed in the main thesis statement and convince the readers about its validity. This can be written well by pointing out any notable faults in the counter-argument(s). just like in any other case, where a writer makes a claim, challenging or agreeing with the thesis statement, enough evidence from academic sources should be added for backup. Thereby the purpose of this section is to convince the reader that regardless of the contrary evidence, the argument by the writer stands strong (Caldwell, 1991: 54).

\subsubsection{Part 5: Conclusion}

The conclusion is the final part of 5-parts of an essay. Fundamentally, it is a section where authors rest the matter. At times, there is a high probability of readers losing bearing of the writer's mission towards the end of the essay. Hence, the writer is supposed to restate the thesis statement in the conclusion section to make the reader remember the original intention of the paper. This should be followed by a summary of claims, including a writer's counter-arguments and refutations. Also, writers should make it clear that their arguments are valid regardless of the distinct opinions of other scholars. Lastly, the final statement should present the authors' concluding view. Here, the learner should convince the readers of the essence of the implementation of their work. That is, they should concentrate on the practical implications of their argument(s) (Atwell, 1987).

\subsection{Elements of a Narrative Essay}

According to (Students" writing: 84-91), A narrative essay encompasses three mandatory elements; Character, theme, and dialogue. 


\subsubsection{Character}

Characters play a crucial role in a narrative essay. Chen, (2011) claimed that even if the essay is naturally autobiographical, the author of the essay is a character connecting some other characters who behave, act, and perform like the other characters present in novels and stories.

\subsubsection{Theme or Motif}

A narrative essay is always linked to a theme or a motif. The theme is portrayed in the thesis statement that further subdivides it into three different pieces of evidence. The three distinct pieces of evidence are then elaborated further by body paragraphs characters. (Cumming 1989:81).

\subsubsection{Dialogue}

Dialogue expresses the conversation between characters. According to Jackson, (2006), dialogue is the third important factor in a narrative essay in which in their absence, the characters lose their liveliness and worth.

Some examples of existing narrative essays in literature;

Example \#1: New Directions (by Maya Angelou)

"Annie, over six feet tall, big-boned, decided that she won't go to work as a domestic and leave her "precious babes" to anyone else's care. There was no possibility of being hired at the town's cotton gin or lumber mill, but maybe there was a way to make the two factories work for her. In her words, "I looked up the road I was going and back the way I come, and since I wasn't satisfied, I decided to step off the road and cut me a new path." She told herself that she wasn't a fancy cook but that she could "mix groceries well enough to scare hungry away and keep from starving a man" (Jackson, 2006: 76).

This paragraph is an instance of a narrative essay of Maya Angelou. She categorically describes how a girl behaves and looks. She has also used direct dialogues to give evidence that it's a narrative (Kementerain 2000: 81).

\section{Example \#2: Saturday Evening Post (by Russell Baker)}

"When I burst in that afternoon she was in conference with an executive of the Curtis Publishing Company. She introduced me. He bent low from the waist and shook my hand. Was it true as my mother had told him, he asked, that I longed for the opportunity to conquer the world of business?

My mother replied that I was blessed with a rare determination to make something of myself.

"That"s right," / whispered.

"But have you got the grit, the character, the never-say-quit spirit it takes to succeed in business?

My Mother said I certainly did".

In this work derived from a narrative essay by Russell Baker of the famed Saturday Evening Post, the writer fully describes his mother's efforts in her dialogue. Both dialogue and character are clear (Lay, 1982: 406).

\subsection{Function of Narrative Essay}

A narrative essay makes descriptions of people, makes presentations of their conversations, and gives their experiences to provide lessons to readers. It's like a story but the difference is that it concentrates on a motif. A motif is provided before essay writing. Readers get familiarized with the theme after going through the essay. Its main aim is to give life experiences information and the lessons that can be obtained from the experiences.

\subsection{Essay Types:}

We have four main categories of essays; descriptive, argumentative, expository, and narratives. Each type has a different role. Some give a story, some are descriptive, and others try to change opinions. One can understand the type of essay well by reviewing several essay examples (Lembaga, 2009).

1. Narrative Essay: Narration portrays you are giving a story from a particular point of view and automatically there is a purpose of giving the story. All narrative essays involve settings, characters, a plot, and climax. The plot is the concentration of the story and is frequently exposed chronologically, but there are flash-forwards and flashbacks at times. 
2. Descriptive Essay: this kind of essay describes people's characteristics, events, objects, and feelings in detail. The topic of description is thoroughly examined. For instance, if you are describing roses, you might want to give a detailed description of their origin, appearance, and color.

3. Expository Essays: these types of essays compare, explore, and discuss issues. Even though they exhibit some sought of storytelling, they aim more than that. It aims to give an explanation of some integral concept to the reader and hence, they describe, inform and explain.

4. Argumentative Essays: in this type of essay, the author tries to convince the reader of something. The author must categorically give the falsity or validity of the theme. The author's statements will be supported by evidence from other scholars. In this case, the author argues for or against a certain issue and supports it with data.

\subsection{Narrative Essay}

A narrative essay gives a narration of a certain event or experience. Narratives contain a point, and the narrative (story) is applied in conveying the point. It encompasses all main events of a story presented categorically based on time. According to (Writing Skills: 77), narrative essays are usually descriptive and sensory information to make the narrator's point and make the story valid. Accordingly, narratives are most of the time subjective and not objective.

\subsection{Effective Teaching}

Various skills, techniques, and practices can make an instructor effective. In my perspective, effective teachers should give an environment that allows learners to learn in their classrooms based on their strengths. Application of effective teaching results in learners creating a love learning surrounding and obtaining new skills on what they are learning. Effective teaching could be a result of various factors such as the attitude of the instructor on the subject, implementation of various styles of learning to lessons and the passion of the subject to be taught.

Applying these ideas can help the teacher be effective in class. According to Hyland, (2008: 92). Effective teaching enables learners to understand new materials better and hard content.

Effective teaching requires more time and extra effort. According to (Cooper 149), effective teaching is a bit more than the process of intuitive. A teacher is supposed to come up with decisions and implement them. As a teacher, somebody should make several decisions regarding instruction planning, develop teaching strategies, and evaluate lesson plan outcomes.

After a lesson, teachers must record any changes for future reference. If the lesson went well, the teacher would have to stick with the strategy in future lessons. Cooper 149 states that the first step of becoming an effective instructor is to acquire the necessary knowledge on the subject matter to be taught in class. Also, in line with the conceptual framework of the NC State's College of Education"s LEAD/SERVE, an effective teacher should give a demonstration of an understanding of the context of education. An effective teacher should have good knowledge of the subjects he teaches. Making the content meaningful is also a crucial way of helping the students in the process of learning. For this to happen, the instructor should know the central concepts, inquiry tools, and the structures of the disciplines he teaches. (INTASC Principles). In my opinion, teaching in a manner that learners can relate to or apply the content in their lives will help them understand it.

Many middle and high school students (and some teachers!) dread those two words: essay writing. But essay writing can be very straightforward and even enjoyable to teach and learn.

\subsection{Characteristics of a Narrative Essay}

In this section, the researcher will explain some of the features and characteristics of the narrative essay (Ridhuan, 2009: 87).

- It aims to inform or to give a story

- The author is a storyteller

- Gives a detailed description of a person, scene, or event

- Information is arranged chronologically.

- Usually written in 1st person voice (using "I"), to some extent informal

- Can incorporate dialogue

- Sample concentrates of the paper:

- One's high school years

- A favorite member of a family

- Quickly make new ideas concerning topics in any subject area.

- Write down information with no self-editing.

- $\quad$ Produce fresh material for more refined work. 


\section{- Complete activities of writing on time, overcome writer's block and improve test-taking skills.}

\section{Analysis and Discussion of the Strategies 3.1 Writing Strategies in Second Language}

Research on the second language writing process started in the early 1980s (for instance, Lay, 1982; Raimes, 1985; Zamel 1983). Second language writing is a difficult procedure of discovery that encompasses brainstorming, numerous drafting, response practices, correction, and last editing. It is distinct from first language (L1) writing in that L2 writers use more than one language at their disposal (Wang \& Wen, 2002). Various studies in the L2 writing process have revealed numerous specific strategies of writing that second language writers use. Writers having various levels of competencies tend to use distinct strategies. According to Zamel (1983), it was evident that the skilled ESL writers in their learning did more revision and used a lot of time in their essays as compared to the unskilled ESL writers. On the other hand, The unskilled ESL learner writers, did less revision and used less time in writing as compared to the skilled learners according to Raimes (1985) protocol-based study that used eight unskilled ESL students as the sample discovered that the L2 writers undertook little planning in the course or before, puts less focus on editing and revising and kept reading their work again and again to create content. The works of (Polio, Fleck \& Leder, 1998) in an investigation of the writing process of $\mathrm{L} 2$ learners, majorly concentrating on revision and editing pointed out the importance of editing and revision in the creation of good essays. The works of Cumming (1989) had earlier revealed that six of his Francophone Canadian adult subjects preferred to use the $\mathrm{L} 1$ for content generation of their writing tasks. The unskilled authors steadily applied their L1 to make concepts, whereas the skilled authors applied L1 for making content and etymological searches (Polio, 1998).

\subsection{Writing Strategies Media}

The teaching and writing skill strategy can come in various forms. Teaching media can be used in the process of teaching as a strategy to give support in material presentation. According to (Rihuan, 2009: 123), instructors must apply appropriate teaching media to attain the benefits of teaching media application.

The works of Rihuan, (2009: 123) argue that the goals of the lessons and characters of learners should be considered while choosing the media. Various aspects should also be selected, including the interest's age, intelligence types, and students' experience. The media cost and convenience of material available are also crucial (Wright 1191 ). In line with these factors, instructors should be capable of selecting appropriate teaching media in the classroom. The use of appropriate teaching media can select supported equipment. One of them is the use of pictures (Rihuan, 2009: 123).

Pictures are used easily and practiced. The pictures media can be portrayed in various ways. Instructors are capable of utilizing a series of pictures to teach learners to understand writing skills in a well-organized text. According to (Zamel, 1983: 165), the series of pictures encompasses several pictures linked together to explain a certain event.

Based on the teaching process of narrative text writing, a series of pictures are appropriate to use. It can support the appropriate process of teaching writing narrative essays. In line with this, the instructor can begin to give a presentation of picture media in the introduction of the genre and give the description of the picture media in a series related to the steps of events in the storytelling process. Presenting the series of pictures to the learners initiates the writing process of writing, particularly the narrative text can result in learners foretelling the steps of the event which occurred in the story sequence. In the end, students are capable of writing a narrative story according to well-organized events (Wang, 2002: 64)

Based on the above results, numerous research has been conducted to determine the benefits of the application of a series of pictures in writing narratives and to determine learners' attitude in the use of the series of pictures in the process of narrative writing and learning. The research findings will be useful to teachers by making learners interested in the process of learning to write narrative and hence become more motivated (Subramaniam, 2004: 54).

It is also anticipated that the application of media and the use of pictures encourages the students to learn and improve their critical thinking and write the narrative well. (Subramaniam, 2004: 54).

In this work, the author concentrated on the effects of applying the series of pictures to improve learners' narrative writing skills. According to the works of Phar and (Pharr, 2005), it is evident that search significance plays a major role in the success of a personal narrative essay. Even though a narrative essay tells a story, but a good narrative story should give the reader or listener a moral lesson. According to (Dornyei, 2010: 47), narratives are different from other kinds of writing. 
Writing is an English language skill that requires writers to be creative in generating their ideas. Students often face difficulties in the writing process as they don't know how to begin a paragraph and construct new sentences. The skill of being a good writer is sometimes difficult even for professionals. According to (Hyland, 2008: 68), students must develop their ideas to be good writers.

In line with the research conducted by (Wright, 1989) in his book Pictures for Language claims that picture is not that a technical aspect but via their representation of places, people and object, they play a major role in the general experience. This implies that pictures can help the students understand a certain word meaning since it's the real representation of the word's meaning (Raimes 1193:27-28). Accordingly, (c.f. Hazem and Kanaan,2020), claimed that pictures portray everything in the outside classroom environment and bring it in class in a vibrantly concreate manner.

\subsection{Generating ideas}

The essence of writing strategies in the writing process has become of great importance and the differences of proficient and less and how appropriate the strategies they apply for works while doing their tasks (Chien, 2010; Hu\& Chen, 2007; Mu \& Carrington, 2007; Ridhuan \& Abdullah, 2009). This portrays the interlink and several connections of crucial factors for the successful implementation of a strategy. Even though students must have several writing strategies in mind, understanding the instructions and requirements of writing in a particular writing task and applying suitable strategy in conducting the task usually determines how effective the strategy will work.

Planning of strategies has been discovered to be of great importance to proficient writers (Mu \& Carrington, 2007; Ridhuan Abdullah, 2009). According to (Chien, 2010), many less proficient learners reported less application of these strategies. Less proficient learners usually don't plan their work as they always start to write immediately (Ridhuan \& Abdullah, 2009). On the contrary, proficient writers spend enough time planning their work before writing. Most of the time, they do drafting and come up with rough plans on how their work will be arranged and hence spend more time planning their work (Ridhuan \& Abdullah, 2009).

According to $\mathrm{Hu}$ and Chen (2007), it was clear that good ESL writers have good prior decisions on what they are going to write and arrange their essays portraying the planning quality significance with time spent planning. Less proficient learners will also spend a lot of time planning, but their efforts bear no fruits due to the implementation of inappropriate strategy and hence produces less quality work. The study of Indra (2004) of the behavior of writers of four writers from various parts of the world, discovered that good Chinese writers planned their ideas by the use of outlines while good Indian writers planned their ideas by putting down visual representations. In comparison, the other weak students that acted as control experiment spent a lot of time in planning that was done mentally and of which it was realized the strategy was ineffective as the method did not give them enough ideas for conducting their tasks (Miller, 2006: 87).

According to the study that was conducted by Ridhuan and Abdullah (2009: 33), it was discovered that both weak and good students shared the same writing strategy in his study that was a cognitive strategy to produce ideas for their tasks. The strategies included rehearsing ideas, rereading, transcribing and repeating, and translating. A study by Chien (2010) reported that the high achievers in his study put more emphasis on generating text, whereas the weak students concentrated on idea generation.

\subsection{Revising Strategy}

Revising strategy is crucial to differentiate strong students from weak students in writing. In line with the works of Chien (2010), good students concentrated on revising and editing. Also, they believed writing is a procedure of idea expression. High achievers in his study made meaningful changes in their tasks and did not put more focus on mechanics only. According to Mu and Carrington (2002), the content revision was considered a basic item by the participant in their study and it was followed by structure and vocabulary. Similarly, all participants including good and weak writers in Hu and Chen"s (2007) study revised mostly lexical and grammatical elements and not discourse structure that shows a surface writing method (Mundriyah, 2016: 121).

The works of Chen (2011) examined the English writing strategies of one hundred and thirty-two Chinese college students revealed that even though the students applied some strategies in the process of writing, they were still not proficient enough in many of the strategies. Data from the questionnaire revealed that the learners applied more strategy in the while-writing stage than prewriting and revising. According to the study done by Baker and Boonkit (2004), it was clear that there was no great difference in the strategies applied by both high and low achievers but there are some slight differences in the kind of strategy they apply. The weak writers often started writing without any plan and always used the translation technique in the entire process of their writing (Heaton, 1995: 51). 


\subsubsection{Promoting Consistency}

Learners at times are confused because of the many requirements and writing format that are needed and varies from subject to subject in a similar school. Even though different subjects need different kinds of writing assignments, all types of writing can follow the same formatting process (Stapa, 2006: 12).

By adopting a consistent and similar writing technique in all subjects within a school, teachers make it easier for students to build confidence in their writing skills techniques (Hu, 2007: 35).

\subsubsection{The Writing Process}

The process of writing encompasses various stages, including the generation of ideas, organizing and developing the idea, and revising and editing the generated ideas. Good writers will ensure they observe keenly all these stages until they archive their target of producing quality work (Hyland, 2008: 91).

\section{Generating Ideas}

In each discipline and academic area, learners have to create skills for obtaining what they know concerning a particular topic and coming up with their ideas and also be capable of finding additional facts. They must also know about confirming if their ideas are in line with the provided theme. Also, they must explain their ideas and the methodology they employed to come up with the idea (Congjun, 2007: 24).

\section{Developing and Organizing Ideas}

Learners should be capable of organizing what is learned in their classrooms into a well-structured document. In long writing tasks, they must have a good knowledge of organizing the work to have a good and focused introduction that captures the reader's attention, connecting the ideas chronologically in the body text, and concluding well in a strong ending. (Chen, 2011: 246).

\section{Revising and Editing}

Learners require group and individual skills to make assessments of their work and those of others to ensure the content is clear, the form and style used is good, and other grammatical and punctuation errors. Learners should always be responsible for the accuracy of their work but also they must also be in a position to help their colleagues improve (Chitravelu,2005: 55).

\section{Generating Ideas: Rapid Writing}

In a situation where learners get engaged in rapid writing at the start of writing assignment, they get access to their previous knowledge, get engaged with content, review and reflect, and start to set directions for writing letters, essays, and any other related academic task (Begurn, 2005: 45).

\section{Generating Ideas: Setting the Context}

Top writers will always predict what their target readers expect to read based on the provided topic. Having an imagination and coming up with possible questions that the target readers may have concerning the topic helps the writer produce good content for the writing, come up with the best writing format strategy, and give a research direction $(\mathrm{Hu}, 2007)$.

\section{Purpose}

- Come up with possible topics and subtopics for a writing task.

- Classify significant ideas and information to add to the writing.

- Identify the target audience and the reason for the writing.

\section{Students will}

- clarify the writing task (purpose, audience, form).

- consider the audience and the purpose of the writing.

- generate questions and use them to focus the writing.

\subsection{Teaching students to write}

When an essay is assigned to students, it may seem very difficult at first glance. Where do we start? How can I cite sources correctly? How do I create a business quote page or reference list? What writing should I apply?

These questions are in students' minds every time. For solving these problems, these tips can be shared with your learners! (Lay, 1982: 16) 


\section{Planning and writing}

The best approach to dealing with an article is to break it down into smaller portions and work with each portion separately. We come up with the shape of each paragraph and after that develop an outline to help in idea arrangement (Heaton, 1995: 82).

\section{Peer review/modification}

Learners can do editing of their tasks in the class. This is of great importance as it gives positive critics to classmates and assists in their writing. We have learners (who are weak in essay writing) who intentionally discuss and share their papers with good students in essay writing. Unfortunately, the good student only cooperates with their colleagues who have equal strength (Mundriyah, 2015: 88)

\section{Peer editing}

According to Zamel (1991), giving the colleague a chance to look at your work and do some corrections and comments gives more chance of thoughts expansion. This enables the peer to give constructive comments and positive criticism on the paper and, hence, improve the writing task. (Zamel, 1991).

\section{Checklists}

Presentation of the final writing work with a checklist is very crucial in the writing process. This ensures that the student loses no material or information. This also helps save time as the student will not have to review and rewrite some sections due to the errors that may arise (Wang, 2002).

\section{Variety}

Giving learners a variety of topics to select will make it easier for them to read similar essay topics severally. Whether personal, compelling narration, or literary, the selection of topics is a simple way to involve various interests (Stapa, 2006).

\subsection{Tips and Clarification}

The purpose is the reason for doing writing and the outcome expectations of the writer from the written document. Some writing aims to communicate information to the target audience. The aims of these writings include explaining, informing, describing, to review and outlining. Other aims make readers convinced of a certain perspective. They include to persuade, to request, to propose, to recommend, to assess, to entertain, and to forecast. The writing will determine the content selection, form and language to be used (Petric, 2003: 187). The audience is the target readers of the writing. Having a clear definition of the audience is significant because it affects the content (what is said) and the features and forms of the writing (how it is said). According to (Writing Skills: 64- 71), the target audience may have a different background, age, experience, and interest.

\section{Conclusion}

The study came up with the following conclusions:

1. Teaching the narrative essay using some strategies has a productive effect on the students' performance.

2. The success of these strategies depends on students' efforts and how to apply them in the writing process.

3. Rapidly create new ideas on topics in any subject area. 4- Write down ideas without self-editing.

4. Generate raw material for more polished work.

5. Complete writing activities early, overcome writer's block, and enhance test-taking skills.

6. Students' information is limited as far as the construction of this type of essay. So the students need to get more information about analyzing and interpreting creating their essays successfully. Furthermore, they have to practice new vocabulary.

7. The role of teachers is very important; they must teach the students how to write good paragraphs.

\section{References}

[1] Begum, R. (2005). A study of the learning strategies of low achievers of English as a Second Language in Selangor, Malaysia. [Unpublished Ph.D. thesis] Universiti Putra Malaysia.

[2] Chen, Y. (2011). Study of the writing strategies used by Chinese non-English majors. Theory and Practice in Language Studies, 1(3), $245-251$. http://dx.doi.org/10.4304/tpls.1.3.245-251

[3] Chien, S. (2010). Enhancing English composition teachers'" awareness of their students" writing strategy use. The Asia-Pacific Education Researcher, 19(3), 417-438.

[4] Chitravelu, N., Sithamparam, S., \& Teh S. C. (2005). ELT Methodology: Principles and Practice, Selangor: Penerbit Fajar Bakti.

[5] Congjun, M., \& Carrington, S. (2007). An investigation of three Chinese students" writing strategies. TESL-EJ, Retrieved December 24, 2010, from http://tesl-ej.org/results.html

[6] Cumming, A. (1989). Writing expertise and second language proficiency. Language Learning, 39, 81-141. 
[7] Dornyei, Z., \& Taguchi, T. (2010). Questionnaires in Second Language Research: Construction, Administration, and Processing (2nd ed.). New York: Routledge.

[8] Hu, G. W., \& Chen, B. (2007). A protocol-based study of university-level Chinese EFL learners" writing strategies. English Australia Journal, 23(2), 37-35. Retrieved December 27, 2010, from http://qa.englishaustralia.com.au/index.cgi? E=hcatfuncs\&PT=sl\&

$\underline{X}=$ getdoc\&Lev1=pub jour 23 \&Lev2= EAJ_23_2_hu

[9] Hyland, K. (2008). Writing theories and writing pedagogies. Indonesian Journal of English Language Teaching.110-11,)2(4,

[10] Jackson, S. L. (2006). Research Methods and Statistics: A Critical Thinking Approach (2nd ed.). USA: Thomson Wadsworth.

[11] Kementerian Pelajaran Malaysia (Ministry of Education). (2000). Sukatan Pelajaran Bahasa Inggeris (English language Syllabus). Kuala Lumpur.

[12] Lay, N. D. S. (1982). Composing processes of adult ESL learners: a case study. TESOL Quarterly, 16(3), 406.

[13] Lembaga Pelajaran Malaysia (Malaysia Education Board). (2009). Pengumuman Analisis Keputusan SPM 2009. Putrajaya.

[14] Nunan, D. (1999). Second Language Teaching and Learning. USA: Heinle \& Heinle Publishers.

[15] Oxford, R. (1990). Language Learning Strategies: What every teacher should know. Rowley: House.

[16] Petric, B., \& Czarl, B. (2003). Validating a writing strategy questionnaire. The system, 31, 187-215. http://dx.doi.org/10.1016\%2Fj.jbtep.2010.12.003

[17] Polio, C., Fleck, N., \& Leder, N. (1998). "If only I had more time": ESL learners" changes in linguistic accuracy on essay revisions. Journal of Second Language Writing, 7, 43-68. http://dx.doi.org/10.1016/S1060-3743(98)90005-4

[18] Raimes, A. (1985). What unskilled ESL students do as they write: A classroom study of composing. TESOL Quarterly, 19(2), 229258.http://dx.doi.org/ 10.2307/3586828

[19] Ridhuan, M., \& Abdullah, T. L. (2009). The writing strategies used by Engineering ESL Malay learners. Conference of the International Journal of Arts \& Sciences. Retrieved December 27, 2010, from http://eprints.utp.edu.my/2035/25.

[20] Stapa, S. H., \& Abdul Majid, A. H. (2006). The use of the first language in limited English proficiency classes: Good, bad, or ugly? Jurnal eBangi, 1(1), 1-12. Retrieved March 28, 2011, from http://eprints.ukm.my/24/1/sitihami-edited1.pdf

[21] Subramaniam, I. D. (2004). The Composing Process of Skilled and Unskilled Chinese and Indian Students: A Case Study. (Unpublished Master Thesis). Univerisiti Kebangsaan Malaysia.

[22] Wang, W. Y., \& Wen, Q. F. (2002). L1 use and English writing quality. Journal of Foreign Languages Research.24-44,4,

[23] Zamel, V. (1983). The composing processes of advanced ESL learners: Six case studies. TESOL Quarterly, 17, 165-187.

[24] Harmer, J. (1991). The Practice of English Language Teaching. New York: Longman Group.

[25] Hazem, A. H., \& Kanaan, M. H. (2020). Domain Adverbs in Legal English Texts: Problems and Strategies. IUP Journal of English Studies, 15(4), 130-141.

[26] Hazem, A. H., \& Mohammed, S. I. (2021). Mitigating Devices in Mosul Iraqi Arabic concerning English. Ijaz Arabi Journal of Arabic Learning, 4(2).

[27] Heaton, J. B. (1995). Writing English Language Test. New York: Longman Inc.

[28] Miller, R. K. (2006). Motives For Writing (Fifth Edition). New York: The McGraw Hill - Companies, Inc.

[29] Mundriyah, M., \& Parmawati, A. (2016). Using Think-Pair-Share (Tps) To Improve Students"writing Creativity (A Classroom Action Research In The Second Semester Students Of Stkip Siliwangi Bandung). P2m Stkip Siliwangi, 3(2), 84-91.

[31] [30] المتراتيجيات التعلم كثيرة ومتنوعة ومهمة للغاية، خاصة عندما يتعلق الأمر بفكرة التعبيروسرد الأحداث .

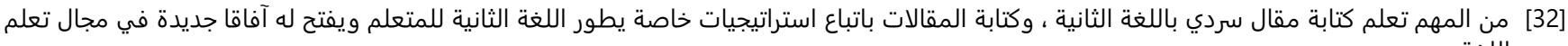

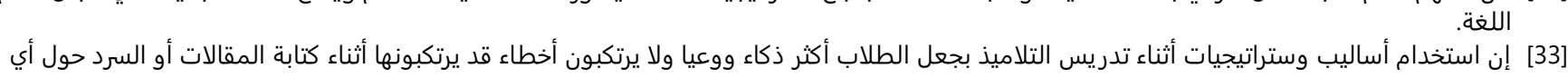

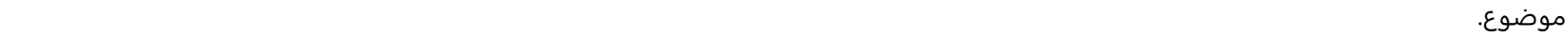
[34] كما يتضمن البحث دراسة كتابة المقالة السردية وكيفية كتابتها وانماطها ومعرفة انواع اخرى للمقالات. كما يحتوي على مجموعة من النصائح حول كتابة المقالة السردية 